\title{
СОЦІАЛЬНА КОМПЕТЕНТНІСТЬ ДІТЕЙ 3 ПОРУШЕННЯМ ІНТЕЛЕКТУАЛЬНОГО РОЗВИТКУ ЯК ПОКАЗНИК ГОТОВНОСТІ ДО НАВЧАННЯ
}

УДК: 376-056.36:37.013.77:005.336.2

\section{Колишкіна Алла Петрівна}

Кандидат педагогічних наук, доиент кафедри доикільної і початкової освіти Сумського держсавного педагогічного університету імені А. С. Макаренка, м. Суми (Украӥна)

\section{Чобанян Анна Варужсаніна}

Старший викладач кафедри спеціальної та інклюзивної освіти Сумського державного педагогічного університету імені А. С. Макаренка, м. Суми (Україна)

\begin{abstract}
Анотація. У статті розглядається питання готовності дітей старшого дошкільного віку з помірною розумовою відсталістю до навчання у школі. Автори особливу увагу приділяють саме соиіальній компетентності, адже вона значно підвищує ефективність адаптації дітей з порушенням інтелектуального розвитку. Особливого значення соиіальний розвиток дитини 3 помірною розумовою відсталістю набуває в аспекті залучення дитини до соиіокультурного середовища. Так, орієнтація національної освіти на особистість дитини зумовлює нову стратегію виховання на основі гуманістичних засад - реалізацію прав дитини із помірною розумовою відсталістю на освіту та забезпечення умов для виявлення своїх можливостей у процесі спеціально організованого навчання і виховання й повноцінного суспільного життя.
\end{abstract}

Ключові слова: готовність до навчання, соціальна компетентність, порушення інтелектуального розвитку, спеціальна дошкільна освіта.

Актуальність проблеми дослідження. відсталістю у систему суспільних відносин. Сучасний етап розвитку нашої країни характеризується низкою соціальних змін та перетворень. Посилення уваги до розвитку особистості, визнання гуманістичних засад виховання як найбільш відповідних принципам правової держави, є однією з передумов повноцінного залучення дітей з помірною розумовою Проблема залучення в соціум завжди була i лишається нині однією з провідних у процесі формування особистості дитини. Відтак, соціальний розвиток є одним із пріоритетних напрямів навчання i виховання дітей із помірною розумовою відсталістю. Він полягає у підготовці дитини до адекватного орієнтуван- 
ня в довкіллі, становленні навичок соціально прийнятної поведінки у різних життєвих ситуаціях

На сьогодні актуальним залишається питання для фахівців галузі спеціальної та інклюзивної освіти щодо підвищення значущості ролі навчання та виховання дітей старшого дошкільного віку з помірною розумовою відсталістю в аспекті формування готовності до навчання у школі та максимально успішного соціального розвитку дітей цієї категоріï.

В нормативно-правових документах можна простежити зміни у підходах до реалізації права на освіту дітей з порушенням інтелектуального розвитку: наказ $\mathrm{MOH}$ від 21.12.2009 р. за № 1153 про заходи Міністерства освіти і науки України на виконання завдань, визначених розпорядженням Кабінету Міністрів України від 3 грудня 2009 року за № 1482-р «Про затвердження плану заходів щодо запровадження інклюзивного та інтегрованого навчання у загальноосвітніх навчальних закладах на період до 2012 року», Наказ МОН України від 11.09.2009 р. за № 855 «Про затвердження Плану дій щодо запровадження інклюзивного навчання у загальноосвітніх навчальних закладах на 2009-2012 роки», змінюють підходи до організаційних форм надання освітніх послуг дітей з особливими потребами. Дитина може навчатися в умовах класу, або індивідуально, за наявністю висновку фахівців ресурсних центрів інклюзивної освіти щодо програм навчання.

Відповідно викладеному вище на практиці виникає потреба формування готовності до навчання у школі дітей старшого дошкільного віку з помірною розумовою відсталістю.

\section{Аналіз наукової літератури $з$ пробле-}

ми. Базовий компонент дошкільної освіти України, визначає державні вимоги до рівня освіченості, розвиненості та вихованості дитини старшого дошкільного віку, а саме сумарний кінцевий показник набутих компетенцій випускником дошкільного навчального закладу перед його вступом до школи. Проте, визначені Базовим компонентом дошкільної освіти вимоги до обсягу необхідної інформації, життєво важливих умінь і навичок, системи ціннісних ставлень до світу та самого себе, у повному обсязі $є$ не придатними для дітей із порушенням інтелектуального розвитку різних ступенів складності. Цей факт пояснюється двома основними клінікопсихологічними законами олігофренії сформульованими Г. Сухарєвою: закон тотальності нервово-психічного недорозвиненості; закон ієрархічності недорозвитку психічної сфери. Під «тотальністю», дослідниця розуміє недорозвиненість усіх нервово-психічних й певною мірою, соматичних функцій, починаючи від недорозвитку внутрішніх органів, опорнорухового апарату, сенсорної, моторної, емоційної сфер, вищих психічних функцій, особливо мислення, мови, особистості в цілому [11]. Ієрархічність недорозвиненості психіч- 
ної сфери, на думку автора проявляється в більш тяжкому ураженні філогенетично обумовлених новітніх новоутворень (моторика та емоційно-вольова сфера виявляються більш збереженими ніж увага, мислення та інтелект).

Аналіз спеціальної науково-методичної літератури, виявив основні теоретичні та практичні положення психолого-педагогічної характеристики різних напрямків підготовки дошкільників 3 порушенням психофізичного розвитку до навчання у школі, а саме теоретичний аналіз поняття «готовність до шкільного навчання» дошкільників (з порушеннями слуху - Л. Головчич, М. Шеремет); умови підготовки дітей до навчання у школі (Т. Сгорова, А. Цимбалюк, М. Шеремет); педагогічна готовність дошкільників з порушеннями психофізичного розвитку (В. Золотоверх Л. Борщевська, I. Ермакова, О. Даниленко, T. Марчук, I. Моргуліс, А. Обухівська, М. Савченко, Т. Свиридюк, Л. Ступнікова, Л. Фомічова, Г. Чефранова, I. Чигринова, С. Шевченко та ін.).

Аналіз робіт зазначених науковців свідчить, що всі вони містять багатий теоретичний та емпіричний матеріал. Водночас, попри наявність різнопланових досліджень, нерозв'язаними залишилися завдання щодо формування готовності до навчання дітей 3 помірною розумовою відсталістю. Вивчення практики дозволило встановити, що особливості психічного розвитку дітей з помірною розумо- вою відсталістю, зумовлюють значні труднощі входження до освітнього простору. Наукові праці присвячені проблемам виховання й навчання дітей з помірною розумовою відсталістю, що конкретизують психічні пізнавальні процеси висвітлено такими науковцями, як Л. Виготський, О. Гаврилов, І. Соловйов, А. Герсамія, Г. Васєнков, Н. Демент'єва, Г. Дульнєв, Л. Занков, М. Певзнер, О. Маллєр, Г. Цикото; розвитку мовленнєвої сфери присвячено праці Р. Бабєнкова, Л. Баряєвої, В. Ліпакової, Н. Лур'є, Я. Юділевич, Л. Шипіциної, А. Грибоєдової, Є. ПравдіноїВінарської; питання щодо розвитку предметно -практичної та ігрової діяльності розглядали Л. Баряєва, С. Забрамна, А. Зарін, Т. Ісаєва. Детальний розгляд особливостей перебігу психічних пізнавальних процесів дітей з помірною розумовою відсталістю дозволив констатувати, що:

- переважна більшість психічних функцій у них знаходиться на елементарному рівні, що безумовно ускладнює виховну роботу 3 дітьми 3 помірною розумовою відсталістю, але не унеможливлює $\dddot{\text { ii }}$ [7, с. 308];

- мовлення дітей 3 помірною розумовою відсталістю характеризується недостатнім словниковим запасом, небажанням користуватись словами 3 пасивного словника, невмінням використовувати наявні мовленнєві знання і вміння у відповідних ситуаціях, значними порушеннями звуковимови та іншими дефектами структури мовлення, які призво- 
дять до відхилень під час вимови і до частого нерозуміння висловлювань таких дітей оточуючими, недостатності мотивів для спілкування, значним недорозвитком комунікативно -пізнавальних здібностей, що виступають основою адаптації індивіда до соціального середовища [4, с. 33];

- поведінка дітей з помірною розумовою відсталістю характеризується реактивністю, вони ще не можуть повністю підпорядковувати одні мотиви іншим, у дітей виникає прагнення до діяльності, але внутрішні мотиви ще не мають достатньої сили, не проявляються у вигляді зовнішньої діяльності [7, с. 308]. Дорослий у цьому випадку виступає тією рушійною силою, яка підштовхує дитину у певному напрямку;

- розвиток навичок самообслуговування та функцій рухового апарату також відстає, таким людям впродовж всього життя потрібна допомога і контроль [14, с.113].

А отже, низький рівень пізнавальних процесів, невміння вбачати конкретну мету, аналізувати і робити висновки, відсутність навиків самоконтролю, невміння спілкуватись, низька мотивація щодо навчання, відсутність життєвих орієнтувань унеможливлюють процес формування інтелектуальної готовності до навчання у школі.

У спеціальній психології визначення готовності до шкільного навчання розумово відсталих дітей здійснено О. Хохліною. Дослідницею встановлено, що готовність дитини до школи стосується усього ï психічного розвитку і передбачає сформованість: позитивного ставлення до школи в цілому та до навчання; пізнавальної та емоційно-вольової сфери, діяльності і довільності поведінки; характерологічних рис, важливих для навчання та діяльності в шкільному колективі. Тобто, важливого значення набуває саме активна позиція дитини 3 порушенням інтелектуального розвитку у процесі навчання [13, с. 2-4]. Аналіз теорії та практики у галузі спеціальної педагогіки засвідчує, що внаслідок причин біосоціального характеру більшість дітей з інтелектуальною недостатністю, що вступають у дошкільні заклади, відзначаються недорозвитком емоційної та комунікативної поведінки, предметних дій, пізнавальних функцій руки, мовлення, Япозиції, прагнення до самостійності, потреби в схваленні та підтримці з боку дорослого, у співробітництві з ним (О. Скжанова, О. Стрєбєлєва та ін.).

Відповідно, діти 3 помірною розумовою відсталістю зіткаються зі значними труднощами при вступі до школи. 3 одного боку, це зумовлено не сформованістю пізнавальної діяльності, а 3 іншого - відсутністю психологічної готовності до входження у новий колектив. Відсутність засобів спілкування з дорослими та однолітками, не сформованість різних видів діяльності, нездатність орієнтуватися у нових та проблемних ситуаціях тощо, веде до того, що подібна комунікативна неспроможність дітей зазначеної категорії залишає їх по- 
за дитячим колективом. Усе це, у свою чергу, сприяє прояву патологічних рис особистості: замкнутості, агресивності, відмові від діяльності (О. Катаєва, Н. Морозова та ін.). Робимо висновок, що дитина з порушенням інтелектуального розвиту старшого дошкільного віку, на відміну від дитини з типовим розвитком, $\epsilon$ менш гнучкою у взаємодії з оточенням та більш залежною від впливів соціального середовища. Все те, що у дитини з типовим розвитком формується спонтанно, завдяки наслідуванню і спільній діяльності з дорослими, у дітей $з$ порушенням інтелектуального розвитку потребує спеціального навчання. До того ж, як наголошують науковці, це стосується не лише розвитку розумових здібностей, а й емоційного розвитку, засвоєння навичок самообслуговування, правил поведінки, формування вміння налагоджувати міжособистісні контакти тощо. Відтак, основна увага дорослих має бути спрямована на соціальний розвиток дитини. Відповідно, спеціальний дошкільний навчальний заклад відіграє важливу роль у формуванні соціальної компетентності дітей 3 порушенням інтелектуального розвитку.

Проблема адаптації розумово відсталих дітей і підлітків широко розглядається сучасними дослідниками (О. Агавелян, А. Раку, Л. Плох, та ін.). Разом з тим, значна частина робіт присвячена, головним чином, вивчення питань соціальної адаптації осіб з інтелектуальною недостатністю, і в набагато меншому ступені вивчалися iї психологічні чинники та механізми (І. Коробейніков, Е. Трошіхіна та ін).

Зокрема, у спеціальній літературі 3 проблем дітей з помірною розумовою відсталістю недостатньо відомостей, що розкривають причини їх несприятливої шкільної адаптації, до яких у віковій психології відносять особливості розвитку різних видів діяльності в молодшому шкільному віці (навчальної, комунікативної та ін.), А також прийняття і виконання дитиною системи шкільних вимог, освоєння програми навчання; становлення рольових відносин з педагогом; індивідуальноособистісні особливості самої дитини; професійно-особистісну готовність педагога до взаємодії і співпраці з дитиною тощо.

У зв'язку з особливостями розвитку, розумово відсталі діти в ще більшій мірі, ніж діти у нормі психофізичного розвитку, потребують цілеспрямованого навчального впливу дорослого. Спонтанне засвоєння суспільного досвіду, особливо в ранньому дитинстві, у них практично не відбувається. Особливе значення ця проблема набуває в період підготовки дитини до школи.

На сьогоднішній день питанням соціалізації дитини з порушенням інтелектуального розвитку присвячено значну кількість досліджень: формування соціально-побутових навичок, забезпечення соціалізації дітей з помірною розумовою відсталістю досліджено О. Маллєр, М. Малофєєв, В. Петрова, Л. Шіпіцина, М. Даниліна, Н. Вайзман; питання форму- 
вання навичок самообслуговування, як пріоритет вирішення завдань їх соціальнотрудової адаптації Г. Блеч, А. Висоцька, О. Гаврилов, Ю. Галецька, І. Гладченко, Л. Дробот, Г. Зак, В. Карвяліс, О. Ковальова, С. Конопляста, В. Лубовський, Н. Лур’ $\epsilon$, О. Маллєр, В. Мачихіна, Г. Мерсіянова, C. Мирський, Н. Павлова, Б. Пінський, I. Татьянчикова, С. Трикоз, О. Чеботарьова, S. Bochner, F. Campbell, C. Kopp.

Відтак, зміни поглядів що відбулися у державі щодо значення та специфіки реалізації процесу навчання і виховання, визнають у процесі соціалізації дитини вже 3 ранніх етапів життя провідної ролі ії індивідуальної картини розвитку. Організація спеціального орієнтованого навчання і виховання є основною формою їх соціальної адаптації та розвитку, соціальний захист. Психологічна наука щодо проблеми навчання і розвитку розумово відсталої дитини виходить із того, що вона інакше розвинена, ніж іï нормальний ровесник. Психічний розвиток дітей $з$ порушенням інтелектуального розвитку кваліфікується як компенсаторний, тобто такий, що здійснюється у формі заміщення, чи вирівнювання того чи іншого внутрішнього процесу (мислення, сприймання тощо). Неприпустима соціальна ідентифікація розумово відсталої дитини, як дитини 3 дефектом. Треба зосередити увагу керівників закладів освіти, педагогів, практичних психологів, соціальних педагогів та в першу чергу корекційних педагогів на пошук нових форм і методів удосконалення освітнього й реабілітаційного процесів, а тому пріоритетним завданням спеціальних дошкільних навчальних закладів на сучасному етапі $є$ компетентнісно-орієнтована освіта, спрямована на формування соціальної компетенції у вихованців з порушенням інтелектуального розвитку.

У наукових працях В. Серової представлено вивчення психологічних особливостей розвитку соціальної компетентності у старших дошкільників 3 порушенням інтелектуального розвитку. Дослідниця звертає увагу на розлади різних типів самоідентифікації у зазначеної категорії дітей, відмічає також системний розлад усіх компонентів соціальної компетентності (когнітивного, емоційного, поведінкового) [10, с. 19-26]. Автор вказує на необхідність розвитку соціального інтелекту, комунікативних навиків, поведінковій саморегуляції в оптимізації процесу формування соціальної компетентності як передумови входження до освітнього простору.

Метою статті $\epsilon$ висвітлення питань соціальної компетентності у дітей з порушенням інтелектуального розвитку як показника готовності до навчання у школі.

Це сприятиме подальшому розвитку наукових основ дошкільної спеціальної педагогіки, поглибленої розробки методик, методичних порад щодо навчання, виховання та корекції дошкільників 3 помірною розумовою відсталістю у плані їх підготовки до навчання 
у школі, перебудови практики роботи спеціального дошкільного навчального закладу, інтегрованих та інклюзивних груп при загальних дошкільних закладах та реабілітаційних центрах, у світі вимог нового педагогічного мислення, а також для забезпечення високої якості професійної підготовки корекційних педагогів дошкільних закладів

\section{Виклад основного матеріалу дослі-} дження. Науковці різних країн світу (Tiffany A. Koszalka (СШA), Insung Jung (Японія), Gila Kurtz (Ізраїль) та ін.), які вивчають наукову категорію «компетентність» в межах діяльності Міжнародного департаменту стандартів для навчання, досягнення та освіти (США) (International Board of Standards for Training, Performance and Instruction (IBSTPI)), трактується іï як спроможність особистості кваліфіковано провадити діяльність, виконувати завдання або роботу. При цьому поняття «компетентність» пов' язується 3 комплексом знань, навичок і ставлень, що дають змогу особистості ефективно діяти або виконувати певні функції, спрямовані на досягнення певних стандартів у професійній галузі або певній діяльності [1, с.1]. Відповідно до «Великого тлумачного словника сучасної української мови», наукова категорія «компетентність» визначається як властивість за значенням «компетентний» і водночас відповідно до освітньо-кваліфікаційного («компетентний»- який має достатні знання в якій-небудь галузі; який з чим-небудь добре обізнаний, тямущий; який грунтується на знанні, кваліфікації), а також управлінського аспектів («компетентний» - який має певні повноваження, повноправний, повновладний) [6].

Ми приєднуємося до означеної позиції вчених щодо тлумачення змісту поняття «компетентність» При цьому знання розуміємо як особливу форму духовного засвоєння результатів пізнання, процесу відображення дійсності, яка характеризується усвідомленням їх істинності. Виражаються знання в поняттях, судженнях, умовиводах, концепціях, теоріях. Знання виконують важливі соціальні функції:

a) матеріалізуються у певні технічні пристрої, технологічні процеси i, таким чином, служать виробництву;

б) перетворюються на переконання і $\epsilon$ керівництвом до практичної дії. Невід'ємними якостями справжніх знань є їх системність, осмисленість [8, с. 137].

Так, у своїх працях В. Куніцина визначає соціальну компетентність як систему знань про соціальну дійсність і про себе , систему складних соціальних умінь і навичок взаємодії, сценаріїв поведінки в типових соціальних ситуаціях, що дозволяють швидко i адекватно адаптуватися [9, с. 34-36.].

Для дослідників (Г. Бурлака, В. Бочарова, П. Павленок, Г. Філонов, М. Фірсов та ін.) видається очевидною необхідність психологічних, соціальних знань, умінь, установок, 
які $\epsilon$ структурними складовими соціальнопсихологічної компетентності у діяльності фахівця соціальної роботи.

Німецькі психологи У. Пфінгстен і Р. Хінтч трактують соціальну компетентність як вміння володіти когнітивними, емоційними і моторними засобами поведінки, які в певних ситуаціях ведуть до довготривалого співвіднесення позитивних і негативних наслідків [2, с. $61-69]$.

Х. Шредер і М. Форверг вважають, що структуру соціальної компетентності складають такі риси особистості: комунікабельність, готовність до спілкування, впливовість, самоповага [3, с. 103-104].

Р. Ульріх і М. Ульріх розробили концепцію, в якій сформульовані основні характеристики соціально-компетентної людини, а саме: розуміння власних почуттів і вимог, вміння аналізувати і включати соціальні знання у власну поведінку, досягнення мети найбільш ефективним чином [4].

Дотичної до теми нашого дослідження $\epsilon$ наукові доробки О. Таран щодо визначення нормативних критеріїв готовності дитини до шкільного навчання, соціальна готовність розглядається дослідницею як складова психологічної готовності дитини до навчання $[12$, с. 126]. Зокрема соціальна готовність складається на думку дослідниці із комунікативної та соціальної компетентності, за такою схемою:

1) комунікативна компетентність, іiі передумови (наявність потреби та бажання ди- тини у спілкуванні з однолітками та дорослими; наявність позитивного ставлення до комунікативної діяльності; сформованість комунікативних рис характеру - товариськість, контактність, відгукуваність, сумлінність, наполегливість тощо.); знання (знання та розуміння мовленнєвої культури спілкування; знання та розуміння невербального спілкування); уміння та навички (сформованість навичок спілкування, уміння вступати в контакт як з однолітками, так і з дорослими; уміння гармонійно поєднувати виразні, вербальні та контакт як 3 однолітками, так і з дорослими; уміння гармонійно поєднувати виразні, вербальні та невербальні засоби спілкування; довільність у спілкуванні з дорослими (уміння прийняти навчальне завдання та вказівку дорослого); здатність до взаємодії на партнерських засадах, (уміння справедливо розподіляти функції, домовлятися, обгрунтовувати свою думку, поступатися, запобігати конфліктам і справедливо їх розв’язувати);

2) соціальна компетентність, їі передумови (усвідомлення свого соціального «Я» (сприймання себе в контексті стосунків 3 іншими, відчуття своєї належності до певної соціальної групи); здатність почувати себе впевнено за межами дому, в іншому соціальному середовищі (відсутність страху, належності до певної соціальної групи); здатність почувати себе впевнено за межами дому, в іншому соціальному середовищі (відсутність страху, нерішучості); знання (знання основ- 
них норм і правил поведінки в соціальному середовищі; розуміння ролі вчителя, що відрізняється від ролі вихователя та матері; розуміння своєї соціальної ролі майбутнього учня, для якого провідна діяльність - навчання); уміння та навички (сформованість навичок суспільного життя, дотримання правил і норм ки навколишніх відповідно норм поведінки; здатність і готовність до співпраці; уміння будувати взаємовідносини з однолітками в процесі спільної діяльності (уміння брати до уваги думку іншого, зважати на нього, доброзичливо взаємодіяти); уміння підпорядковувати свою поведінку законам дитячої групи; здатність знаходити своє місце в групі; думку іншого, зважати на нього, доброзичливо взаємодіяти); уміння підпорядковувати свою поведінку законам дитячої групи; здатність знаходити своє місце в групі; здатність виконувати роль учня в ситуації шкільного навчання; сформованість необхідних елементарних трудових умінь та навичок (уміння організувати робоче місце та підтримувати порядок на ньому тощо); сформованість навичок самообслуговування).

Соціальна компетентність, в свою чергу виступає як система структурованих знань про закономірності поведінки, діяльності і відносин, які проявляються через особистісні якості людини, що забезпечують відповідальне саморегулювання поведінки особистості в суспільстві, передбачає володіння складними комунікативними навичками, формування поведінки; уміння об'єктивно оцінювати вчин-

адекватних умінь в нових соціальних умовах. У найповнішому вигляді соціальна компетентність передбачає певний обсяг знань і рівень сформованості умінь та навичок, що дозволяють людині адекватно орієнтуватися в різних ситуаціях, об'єктивно оцінювати себе і людей, здійснювати самоаналіз і самоконтроль, прогнозувати поведінку інших осіб, формувати необхідні відносини і успішно впливати на них, орієнтуючись на наявні умови.

Діти старшого дошкільного віку з помірною розумовою відсталістю у соціальному розвитку значно відрізняються від своїх однолітків з типовим розвитком. Певною мірою це обумовлено не лише органічним ураженням але й умовами виховання дітей $з$ помірною розумовою відсталістю в родині: неадекватними формами спілкування, характером взаємодії дорослого з дитиною, ізоляцією дитини від однолітків й інших дорослих, невідповідністю предметно-розвиваючого середовища до потенційного рівня психічного розвитку дитини. В результаті проведення аналізу психологопедагогічної літератури по вивченню особливостей соціального розвитку дітей дошкільного віку з помірною розумовою відсталістю, виокремлюють загальні компоненти в соціальному розвитку, несформованість яких значно ускладнювало включення цих дітей в середу однолітків і подальшу соціалізацію:

- $\quad$ вміння співпрацювати з новим дорослим і однолітками;

- $\quad$ діяти спільно або по наслідуванню в різних видах діяльності; 
- $\quad$ адекватно поводитися в побуті, підкорятися режиму дня;

- володіння навичками охайності і самообслуговування (вміння одягатися і роздягатися, вмиватися, розчісуватися, прибирати свої речі в шафу 3 допомогою дорослого або самостійно).

Як показують теоретичні дані, основною причиною несвоєчасного включення дітей старшого дошкільного віку 3 помірною розумовою відсталістю у соціум $є$ неадекватна соціальна ситуація їх ви в сім'ї. Дослідники, визначають ряд факторів, що ускладнюють соціальний розвиток дітей старшого дошкільного віку з помірною розумовою відсталістю.

1) неадекватні форми спілкування і взаємодії матері зі своєю дитиною;

2) невміння батьків ввести дитину в нове соціальне оточення;

3) ізоляція дитини з порушенням інтелектуального розвитку від оточуючих людей;

4) недооцінка батьками наслідків втрати часу сенситивного періоду в соціальному розвитку дитини;

5) відсутність організованого режиму дня дитини в родині;

6) відсутність адекватного предметнорозвиваючого середовища для дитини в сім'ї.

Таким чином, у дітей дошкільного віку 3 помірною розумовою відсталістю особливості соціального розвитку є різнорівневими в основних показниках і свідчать як про соціальну непристосованості дитини в сім'ї, так i про несформованість компонентів готовності до включення в колектив однолітків.

Показниками соціального розвитку дітей дошкільного віку з помірною розумовою відсталістю виступають:

- форма спілкування дитини з дорослим;

- $\quad$ засоби спілкування дитини з дорослим;

- $\quad$ сформованість у дитини уявлень про себе;

- сформованість уявлень про інших людей;

- $\quad$ сформованість уявлень про навколишній світ,

- адекватність використання предметів оточення;

- способи засвоєння суспільного досвіду;

- адекватність поведінки в незнайомій обстановці;

- сформованість соціально-побутових умінь і навичок, в тому числі жестів, мови і малюнків.

Вищезазначене, певною мірою висуває нові вимоги перед родиною у питаннях взаємодії із фахівцями закладів спеціальної освіти в процесі формування соціальної готовності розумово відсталої дитини до навчання у спеціальній загальноосвітній школі, адже фахівці галузі спеціальної освіти є більш компетентними за батьків у питаннях розв'язання проблем розумово відсталих дітей. Тому, важливим стає питання узгодження впливів усіх суб’єктів (батьків, вихователів, логопедів, психологів) виховного процесу на дітей з помір- 
ною розумовою відсталістю за для формування психологічної готовності дітей до навчання у спеціальній загальноосвітній школі. Відомий психолог О. М. Леонтьєв зазначає, що близьке оточення дитини, можна віднести до системи виховних впливів до яких вона чутлива. Сучасна наука наголошує на важливості сімейного виховання для повноцінного розвитку особистості дитини, оскільки його сила та вплив не порівнюються $з$ жодним, навіть 3 дуже кваліфікованим вихованням у дитячому садку чи школі. Психологічні та соціальнопедагогічні дослідження дозволяють стверджувати, що сім'я посідає важливе місце серед соціальних груп, які впливають на формування особистості. Саме сім'я 3 іiі інтимноособистими зв'язками, як ніяка суспільна установа, може забезпечити дитині емоційний захист, відчуття важливості та суттєвості свого існування, щирої зацікавленості в ній. Немає таких якостей особистості, у формуванні яких не брала б участь сім'я. Любов дитини до батьків, виступає гарантом емоційного благополуччя й безпеки. Дитині мало просто того, щоб іiі любили. Вона потребує підтримки на всіх періодах дитинства, особливо при розумовій відсталості. Глибокий, постійний контакт $з$ дитиною - необхідна умова їі виховання у будь-якому віці. Але тісний контакт і взаєморозуміння не виникають самі по собі. Батьки їх будують і творять, починаючи з віку немовляти.

Висновки. Можна 3 більшою чи 3 мен- шою вірогідністю констатувати, що у дитини старшого дошкільного віку з помірною розумовою відсталістю, знижені відповідні позитивні психологічні передумови до соціокультурного розвитку. Дитина з порушенням інтелектуального розвитку може досягти соціальних адекватних соціальних стандартів. Психологічна позиція винятковості, своєрідності призводить до того, що ставлення до такої дитини соціального оточення визначається суспільно встановленим виміром. За відсутності чи недостатньої ефективності роботи у цьому напрямі у дітей з порушенням інтелектуального розвитку формується підозрілість, недовіра стосовно оточуючих. Дитина може компенсувати власні психологічні труднощі відповідними агресивними діями стосовно соціального середовища у якому вона перебуває. Можна стверджувати те, що організація спеціального орієнтованого навчання і виховання $\epsilon$ основною формою їх соціальної адаптації та розвитку. А тому, ключовим моментом формування готовності до навчання у школі дітей 3 помірною розумовою відсталістю, може виступити принцип створення адекватних умов для виховання на розвитку, з метою якомога раннього запобігання соціальної депривації, обумовленої перебуванням дитини з порушенням інтелектуального розвитку у специфічному, замкненому, обмеженому середовищі. За такого підходу у старших дошкільників 3 помірною розумовою відсталістю значно підвищуватиметься соціальна позиція й рівень са- 
мооцінки. Освітньою стратегією щодо дітей 3 порушенням інтелектуального розвитку має бути орієнтація на підвищення їх соціальної позиції. Вплив корекційного педагога, спеціального психолога має спрямовуватися на нагромадження такою дитиною внутрішнього, психічного потенціалу для несуперечливого повернення іiі в зону соціокультурної дії - розумової, трудової, комунікативної, моральної.

Перспективи подалыших досліджень. Актуальною для нашого дослідження є питання взаємодії фахівців спеціального дитячого навчального закладу і сім’ї дитини 3 помірною розумовою відсталістю. Ми висунули припущення, що об'єднання професійної компетентності фахівців спеціального дошкільного навчального закладу із педагогічною компетентністю сімей дітей 3 помірною розумовою відсталістю буде ефективним засобом формування соціальної готовності дитини 3 порушенням інтелектуального розвитку до навчання у спеціальній загальноосвітній школі. На нашу думку, взаємодія фахівців спеціального дитячого навчального закладу та сім’і дитини з помірною розумовою відсталістю складна проблема, що проходить тривалий розвиток, набуваючи особливого значення у пошуку дієвих шляхів іiї розв'язання на сучасному етапі розвитку спеціальної освіти. Зазначена ситуація ускладнюється тим, що сьогодні традиційно робота з сім'ями дітей $з$ помірною розумовою відсталістю здійснюються як складова психолого-педагогічного супроводу ді- тей означеної нозології, що не дозволяють повністю задовольнити потреби батьків у різних видах соціальних послуг (психологопедагогічних), а отже, потребують творчого переосмислення.

\section{Перелік використаних джерел:}

1. Spector J. Michael-de la Teja, Ileana. ERIC Clearinghouse on Information and Technology Syracuse NY. Competencies for Online Teaching. ERIC Digest. Competence, Competencies and Certification. - P. 1.

2. Phingsten $U$. Gruppentraining sozialer Kompetenzen. / Phingsten U., Hintesch R. - Weinheim: Psychologies Verlag Union, 1991. - P. 61 - 69.

3. Shroder H. Soziale Kompetenz als Zielgrosse fur Personlichkeitstruktur und Verhaltensmodifikation. Zur psychologishen Personlichkeitsforschung / H. Shroder, M. Vorwerg. - Berlin, 1978. - $230 \mathrm{p}$.

4. Ullrich R. Diagnose und Therapie sozialer storungen. Das Assertiveness - Trainings - ProgrammeATP / Ullrich R., Ullrich de Muynck R - Munchen: Pfeiffer, 1980. - 284 $\mathrm{p}$.

5. Бгажнокова И. М. Воспитание и обучение детей и подростков с тяжелыми и множественными нарушениями развития / под ред. И.М. Бгажноковой. - М. : ВЛАДОС, 2007. -239 с

6. Великий тлумачний словник сучасної української мови (з додатками, доповненнями та $\mathrm{CD}$ ) / [уклад. та гол. ред. В. Т. Бусел]. - К. ; Ірпінь : ВТФ „Перун”, 2009. $-1736 \mathrm{c}$.

7. Гаврилов О. В. Особливі діти в закладі і соціальному середовищі : навч. посібник / О. В. Гаврилов - Кам'янець-Подільський : Аксіома, 2009. - 308 с.

8. Гончаренко C. Український педагогічний словник / Семен Гончаренко. - К. : Либідь, 1997. - 376 с.

9. Куницина В. Н. Социальный интеллект и социальная компетентность / В.Н. Куницина // Тезисы научно- 
практической конференции «Б. Г. Ананьев и ленинградская школа в развитии современной психологии»Спб.: Изд-во СпбГУ, 1995. - С. 34-36.

10. Серова B. B. Развитие социальной компетентности у старших дошкольников с ЛФПН-воспитанников детского дома/ Коррекционная педагогика.-2012.-№1 (48).c. $19-26$.

11. Сухарева Г. Е. Клинические лекции по психиатрии детского возраста, т. I. М., 1955; т. II, 1959; т. III. 1963

12.Таран О.П. Психологічна готовність дитини до школи / О. Таран // Психолог. Бібліотека. - 2010. - № 9. - С. $5-126$.

13. Хохліна О. П., Козленка М.О., Мерсіянова Г.М., Турчинська В.С. Проект концепції державного стандарту освіти розумово відсталих учнів // Дефектологія. — 2000 . — № 1 . - C 2 - 4 .

14. Юдилевич Я. Г. Опыт обучения и воспитания глубоко умственно отсталых детей (имбецилов) / Я. Г. Юдилевич // Вопросы обучения и воспитания детей с нарушением интеллекта / Под ред. М.И. Кузьмицкой. - М. : Изд-во АПН РСФСР, 1974. - 113 с.

\section{References (Transliteration):}

1.Spector J. Michael-de la Teja, Ileana. ERIC Clearinghouse on Information and Technology Syracuse NY. Competencies for Online Teaching. ERIC Digest. Competence, Competencies and Certification. - P. 1.

2. Phingsten $U$. Gruppentraining sozialer Kompetenzen. / Phingsten U., Hintesch R. - Weinheim: Psychologies Verlag Union, 1991. - P. 61 - 69.

3. Shroder H. Soziale Kompetenz als Zielgrosse fur Personlichkeitstruktur und Verhaltensmodifikation. Zur psychologishen Personlichkeitsforschung / H. Shroder, M. Vorwerg. - Berlin, 1978. - $230 \mathrm{p}$.

4. Ullrich $R$. Diagnose und Therapie sozialer storungen. Das Assertiveness - Trainings - ProgrammeATP / Ullrich R., Ullrich de Muynck R - Munchen: Pfeiffer, 1980. 284 p.

5. Bghazhnokova Y. M. Vospytanye y obuchenye detej y podrostkov s tjazhelumy y mnozhestvennumy narushenyjamy razvytyja / pod red. Y.M. Bghazhnokovoj.- M. : VLADOS, 2007. - $239 \mathrm{~s}$

6. Velykyj tlumachnyj slovnyk suchasnoji ukrajinsjkoji movy (z dodatkamy, dopovnennjamy ta $\mathrm{CD}$ ) / [uklad. ta ghol. red. V. T. Busel]. - K. ; Irpinj : VTF „Perun”, 2009. $1736 \mathrm{~s}$.

7. Ghavrylov O. V. Osoblyvi dity v zakladi i socialjnomu seredovyshhi : navch. posibnyk / O. V. Ghavrylov - Kam'janecj-Podiljsjkyj : Aksioma, 2009. - 308 s.

8. Ghoncharenko S. Ukrajinsjkyj pedaghoghichnyj slovnyk / Semen Ghoncharenko. - K. : Lybidj, 1997. - 376 S.

9. Kunycyna $V$. N. Socyaljnuj yntellekt y socyaljnaja kompetentnostj / V.N. Kunycyna // Tezysu nauchnopraktycheskoj konferencyy «B.Gh. Ananj'ev y lenynghradskaja shkola $\mathrm{V}$ razvytyy sovremennoj psykhologhyy»-Spb.: Yzd-vo SpbGhU, 1995. - S. 34-36. 10. Serova $V$. $V$. Razvytye socyaljnoj kompetentnosty u starshykh doshkoljnykov s LFPN-vospytannykov detskogho doma/ Korrekcyonnaja pedaghoghyka.-2012.-\#1 (48).-s. 19-26.

11. Sukhareva Gh. E. Klynycheskye lekcyy po psykhyatryy detskogho vozrasta, t. I. M., 1955; t. II, 1959; t. III. 1963

12. Taran O. P. Psykhologhichna ghotovnistj dytyny do shkoly / O. Taran // Psykhologh. Biblioteka. - 2010. - \# 9. S. 5-126.

13. Khokhlina O. P., Kozlenka M. O., Mersijanova Gh. M., Turchynsjka V. Je. Proekt koncepciji derzhavnogho standartu osvity rozumovo vidstalykh uchniv // Defektologhija.— 2000 . — \# 1 . - S $2-4$.

14. Judylevych Ja. Gh. Oput obuchenyja y vospytanyja ghluboko umstvenno otstalukh detej (ymbecylov) / Ja. Gh. Judylevych // Voprosu obuchenyja y vospytanyja detej s narushenyem yntellekta / Pod red. M.Y. Kuzjmyckoj. - M. : Yzd-vo APN RSFSR, 1974. - 113 s. 


\section{Kolyshkina Alla}

Candidate of Pedagogical Sciences, Assistant Professor at Department of Preschool and Primery Education of A. S. Makarenko Sumy State Pedagogical University, Sumy (Ukraine)

\section{Chobanyan Anna}

Lecturer at Department of Special and Inclusive Education of A. S. Makarenko Sumy State Pedagogical University, Sumy (Ukraine)

\section{SOCIAL COMPETENCE OF CHILDREN WITH INTELLECTUAL DISABILITY AS AN INDICATOR OF READINESS FOR EDUCATION}

\section{ABSTRACT}

The article discusses the readiness of children of senior preschool age with moderate mental retardation to schooling. The authors pay special attention to social competence, because it significantly improves the adaptation of children with intellectual disabilities to schooling. Of particular importance is the social development of a child with moderate mental retardation in the aspect of attracting a child to the socio-cultural environment. The study of special methodological psychological and pedagogical literature made it possible to establish that the organization of special oriented instruction and upbringing is the main form of their social adaptation and development. That is why the principle of creating the conditions for the least possible social deprivation, that is, the placement of a mentally retarded child in the least specific, closed, restricted environment, can become the key moment of the readiness for the education of children with moderate mental retardation in school. It is possible to state with greater or lesser probability that the child of the older preschool age with moderate mental retardation has lowered the corresponding positive psychological prerequisites for sociocultural development. A child with a violation of intellectual development can achieve social standards that are adequate to a normal child. With this approach, the mentally retarded schoolchildren significantly increase their social position and level of self-esteem.

The psychological position of exclusivity, originality leads to the fact that the attitude to such a child of a social environment is determined by a socially established dimension. The educational strategy for mentally retarded children should be to focus on minimizing their social position as little as possible. In the absence or inadequate efficiency of work in this direction, in children with intellectual disabilities, suspicion is formed, distrust in relation to others. A child can compensate for his/her own psychological difficulties by appropriate aggressive actions in relation to the social environment in which it is located. The influence of the correctional teacher, a special psychologist, should be directed toward the accumulation by such a child of an internal, mental potential for a non-contradictory return to a zone of sociocultural action-mental, labor, communicative, and moral. Indicators of social development of preschool children with moderate mental retardation are: the form of communication between the child and the adult; means of communication between the child and 
the adult; formation of the child's self-image; the formation of ideas about other people; the formation of ideas about the surrounding world, the adequacy of the use of environmental objects; ways to assimilate social experience; adequacy of behavior in unfamiliar surroundings; the formation of social and everyday skills and habits, including gestures, language and drawings. However, despite the conducted studies, the experience of forming social readiness for teaching children of the senior preschool age with moderate mental retardation remains insufficiently studied.

Thus, the orientation of national education on the personality of the child predetermines a new strategy of education on the basis of humanistic principles-the realization of the rights of a child with moderate mental retardation for education and the provision of conditions for identifying its possibilities in the process of specially organized education and upbringing and social life.

Key words: readiness for training, social competence, intellectual development violations, special pre-school education.

\section{Колышкина Алла Петровна}

Кандидат педагогических наук, доиент кафедры дошкольного і начального образования Сумского государственного педагогического университета имени А. С. Макаренко, г. Сумыл (Украина)

\section{Чобанян Анна Варужановна}

Старший преподаватель кафедры коррекиионного и инклюзивного образования Сумского государственного педагогического университета имени А. С. Макаренко, 2. Сумы (Украина)

\section{СОЦИАЛЬНАЯ КОМПЕТЕНТНОСТЬ ДЕТЕЙ С НАРУШЕНИЕМ ИНТЕЛЛЕКТУАЛЬНОГО РАЗВИТИЯ КАК ПОКАЗАТЕЛЬ ГОТОВНОСТИ К ОБУЧЕНИЮ}

Аннотация. В статье рассматривается вопрос готовности детей старшего дошкольного возраста с умеренной умственной отсталостью к обучению в школе. Авторы особое внимание уделяют именно социальной компетентности, ведь она значительно повышает эффективность адаптации детей с нарушением интеллектуального развития. Особое значение социальное развитие ребенка с умеренной умственной отсталостью приобретает в аспекте привлечения ребенка к социокультурной среде. Изучение специальной методической психолого-педагогической литературы, позволило установить, что организация специального ориентированного обучения и воспитания является основной формой их социальной адаптации и развития. А потому, ключевым моментом формирования готовности к обучению в школе детей с умеренной умственной отсталостью, может выступить принцип создания условий для как можно меньшей социальной депривации, то есть размещение умственно отсталого ребенка в наименее специфической, замкнутой, ограниченной среде. Можно с большей или с меньшей вероятностью констатировать, что у ребенка старшего дошкольного возраста с умеренной умственной отсталостью, снижены соответствующие положительные психологические предпосылки к социо- 
культурному развитию. Ребенок с нарушением интеллектуального развития может достичь социальных стандартов, адекватных нормотипичному ребенку. При таком подходе у школьников с нарушением интеллекта значительно повышаться социальная позиция и уровень самооценки.

Психологическая позиция исключительности, своеобразия приводит к тому, что отношение к такому ребенку социального окружения определяется общественно установленным измерением. Образовательной стратегией для детей с нарушением интеллектуального развития должна стать ориентация на как можно меньшее снижение их социальной позиции. При отсутствии или недостаточной эффективности работы в этом направлении у детей с нарушением интеллекта формируется подозрительность, недоверие по отношению к окружающим. Ребенок может компенсировать собственные психологические трудности соответствующими агрессивными действиями в отношении социальной среды, в котором он находится. Влияние коррекционного педагога, специального психолога должно направляться на накопление таким ребенком внутреннего, психического потенциала для непротиворечивого возвращению его в зону социокультурного действия - умственного, трудового, коммуникативного, нравственного. Показателями социального развития де-

тей дошкольного возраста с умеренной умственной отсталостью выступают: форма общения ребенка со взрослым; средства общения ребенка со взрослым; сформированность у ребенка представлений о себе; сформированность представлений о других людях; сформированность представлений об окружающем мире, адекватность использования предметов окружения; способы усвоения общественного опыта; адекватность поведения в незнакомой обстановке; сформированность социально-бытовых умений и навыков, в том числе жестов, речи и рисунков.

Так, ориентация национального образования на личность ребенка предопределяет новую стратегию воспитания на основе гуманистических принципов - реализацию прав ребенка с умеренной умственной отсталостью на образование и обеспечение условий для выявления своих возможностей в процессе специально организованного обучения и воспитания, общественной жизни.

Ключевые слова: готовность к обучению, социальная компетентность, нарушение интеллектуального развития, специальное дошкольное образование.

Дата отримання статті: 17.01.2018 Дата рекомендації до друку: 19.01.2018 